\title{
Opposing Role of Dopamine D1 and D2 Receptors in Modulation of Rat Nucleus Accumbens Noradrenaline Release
}

\author{
Louk J. M. J. Vanderschuren, George Wardeh, Taco J. De Vries, Arie H. Mulder, and \\ Anton N. M. Schoffelmeer \\ Research Institute Neurosciences Vrije Universiteit, Department of Pharmacology, Medical Faculty, Free University, \\ Amsterdam, The Netherlands
}

The role of dopamine receptors in the modulation of nucleus accumbens noradrenaline release was investigated in superfused rat brain slices. At concentrations of $\leq 1 \mu \mathrm{M}$, dopamine enhanced, whereas at higher concentrations dopamine inhibited electrically evoked $\left[{ }^{3} \mathrm{H}\right]$ noradrenaline release. The $\mathrm{D} 1 \mathrm{re}-$ ceptor agonist SKF-38393 increased, whereas the D2 agonist quinpirole inhibited evoked $\left[{ }^{3} \mathrm{H}\right]$ noradrenaline release. These effects were attenuated by the D1 antagonist $\mathrm{SCH}-23390$ and the D2 antagonist (-)-sulpiride, respectively, indicating that accumbens noradrenaline release is regulated by stimulatory D1 and inhibitory D2 receptors. Whereas (-)-sulpiride enhanced, SCH-23390 did not reduce evoked accumbens $\left[{ }^{3} \mathrm{H}\right]$ noradrenaline release, indicating a tonic activation of D2 receptors only. Given the similar apparent affinity of dopamine for D1 and D2 receptors in striatal slices, the lack of tonic D1 receptor activation suggests that D1, unlike D2, receptors are extrasynaptically localized. No dopaminergic modulation of noradrenaline release was observed in rat medial prefrontal cortex or amygdala slices. To examine the regulation of accumbens noradrenaline release under conditions of increased dopaminergic activity, measurements were made using slices of amphetamine-pretreated rats. In these slices, the electrically evoked release of $\left[{ }^{3} \mathrm{H}\right]$ dopamine and $\left[{ }^{3} \mathrm{H}\right]$ noradrenaline was enhanced. The increasing effect of $(-)$-sulpiride on noradrenaline release was augmented, and $\mathrm{SCH}-23390$ almost completely reversed this enhancement of $\left[{ }^{3} \mathrm{H}\right]$ noradrenaline release. These data suggest that whereas although under a moderate dopaminergic tone, accumbens noradrenaline release is mainly regulated by inhibitory D2 receptors, under circumstances of increased dopaminergic activity, recruitment of extrasynaptic stimulatory D1 receptors contributes to enhancement of noradrenaline release.

Key words: noradrenaline release; nucleus accumbens; dopamine release; dopamine $D 1$ receptor; dopamine $D 2$ receptor; amphetamine
Because of extensive and reciprocal connections with limbic and motor systems, the nucleus accumbens (NAcc) is thought to be important for the generation of motor responses to emotionally relevant environmental stimuli (Mogenson, 1987; Kalivas et al., 1993). The dopaminergic projection from the ventral tegmental area to the NAcc, part of the so-called mesolimbic dopamine (DA) system, has received particular attention in this respect. For instance, NAcc DA neurotransmission has been shown to be involved in exploratory behavior, in the psychomotor and reinforcing effects of drugs of abuse, and in appetitive and preparatory behaviors. This has led to the general assumption that the mesolimbic DA system plays a key role in goal-directed and motivational behavior (Le Moal and Simon, 1991; Phillips et al., 1991; Koob, 1992; Amalric and Koob, 1993; Salamone, 1994; Schultz et al., 1997).

Interactions between the various inputs into the NAcc can be expected to serve to optimize information flow necessary for the generation of adaptive motor responses. In this respect, it has been shown recently that the shell portion of the NAcc receives a

\footnotetext{
Received Nov. 23, 1998; revised Feb. 22, 1999; accepted March 2, 1999.

This work was supported by the Netherlands Organization for Scientific Research (NWO) Grant 903-42-007.

Correspondence should be addressed to Dr. Louk J. M. J. Vanderschuren, Research Institute Neurosciences Vrije Universiteit, Department of Pharmacology, Medical Faculty, Free University, Van der Boechorststraat 7, 1081 BT Amsterdam, The Netherlands.

Copyright (C) 1999 Society for Neuroscience $\quad 0270-6474 / 99 / 194123-09 \$ 05.00 / 0$
}

dense noradrenaline (NA)-containing projection, originating primarily in the nucleus tractus solitarius (NTS) (Berridge et al., 1997; Delfs et al., 1998). Because there is very little information on the possible interaction between NAcc NA and DA systems (Nurse et al., 1984; Yavich et al., 1997), we investigated here the role of DA receptor stimulation on electrically evoked NA release from rat NAcc slices in vitro.

Extracellular concentrations of NAcc DA and NA are enhanced by systemically and locally applied psychostimulant drugs, such as amphetamine and cocaine (Di Chiara and Imperato, 1988; Seiden et al., 1993; McKittrick and Abercrombie, 1997; Reith et al., 1997), and psychostimulant-induced locomotion is known to rely on increases in NAcc DA neurotransmission (Kelly et al., 1975; Pijnenburg et al., 1975; Delfs et al., 1990; Amalric and Koob, 1993). In addition, involvement of NA in the psychomotor effects of amphetamine and cocaine has also been demonstrated (Snoddy and Tessel, 1985; Dickinson et al., 1988; Harris et al., 1996). With regard to repeated exposure to psychostimulants, there is ample evidence that this causes NAcc DA nerve terminals to become hypersensitive (Kalivas and Stewart, 1991; Nestby et al., 1997; Pierce and Kalivas, 1997). If NAcc NA neurotransmission is modulated by DA, this regulation might be altered as a result of psychostimulant-induced increase in DA tone. Therefore, we also investigated the effects of DA receptor activation on NA release in NAcc slices of rats repeatedly treated with amphetamine. This is of particular interest given the notion that the neuroadaptations occurring after repeated psychostimulant expo- 
sure are involved in drug-induced addiction and psychosis (Robinson and Becker, 1986; Robinson and Berridge, 1993).

\section{MATERIALS AND METHODS}

Animals and drug pretreatments. All experiments were approved by the Animal Care Committee of the Free University of Amsterdam. Male Wistar rats (Harlan CPB, Zeist, The Netherlands), weighing 180-200 gm at the time of arrival in the laboratory, were housed two per cage in Macrolon cages under controlled conditions (lights on from 7:00 A.M. to 7:00 P.M.) for 1 week before use. Food and water were available ad libitum. Animals receiving drug pretreatment were briefly handled on the $2 \mathrm{~d}$ preceding the beginning of treatment. Pretreatment consisted of intraperitoneal injections with $2.5 \mathrm{mg} / \mathrm{kg}(+)$-amphetamine or saline, administered once daily on 5 consecutive days. Three days after the last injection, the animals were killed, and neurotransmitter release was determined as described below.

Determination of neurotransmitter release. Rats were decapitated, their brains were rapidly removed, and NAcc (including core and shell), medial prefrontal cortex, or amygdala were dissected from a 1-mm-thick coronal slice using the atlas of Paxinos and Watson (1986). Slices $(0.3 \times$ $0.3 \times 1 \mathrm{~mm}$ ) were prepared using a McIlwain tissue chopper and incubated and superfused as described previously (Schoffelmeer et al., 1994). Briefly, slices were washed twice with Krebs'-Ringer's bicarbonate medium containing (in $\mathrm{mM}$ ) $121 \mathrm{NaCl}, 1.87 \mathrm{KCl}, 1.17 \mathrm{KH}_{2} \mathrm{PO}_{4}, 1.17$ $\mathrm{MgSO}_{4}, 1.22 \mathrm{CaCl}_{2}, 25 \mathrm{NaHCO}_{3}$, and $10 \mathrm{D}-(+)$-glucose and subsequently incubated for $15 \mathrm{~min}$ in this medium under a constant atmosphere of $95 \% \mathrm{O}_{2}-5 \% \mathrm{CO}_{2}$ at $37^{\circ} \mathrm{C}$. After preincubation, the slices were rapidly washed and incubated for $15 \mathrm{~min}$ in $2.5 \mathrm{ml}$ of medium containing $5 \mu \mathrm{Ci}$ of $\left[{ }^{3} \mathrm{H}\right] \mathrm{NA}$ or, in one set of experiments, $5 \mu \mathrm{Ci}$ of $\left[{ }^{3} \mathrm{H}\right] \mathrm{DA}$ under an atmosphere of $95 \% \mathrm{O}_{2}-5 \% \mathrm{CO}_{2}$ at $37^{\circ} \mathrm{C}$. Because the brain areas investigated have both dense dopaminergic and noradrenergic innervations, $1 \mu \mathrm{M}$ GBR-12909 was added to the medium during incubation to prevent accumulation of $\left[{ }^{3} \mathrm{H}\right] \mathrm{NA}$ in DA nerve terminals, or $3 \mu \mathrm{M}$ desipramine was added during incubation to prevent accumulation of $\left[{ }^{3} \mathrm{H}\right] \mathrm{DA}$ in NA nerve terminals. After labeling, the slices were rapidly washed and transferred to each of 24 chambers of a superfusion apparatus ( $\sim 4 \mathrm{mg}$ of tissue in $0.2 \mathrm{ml}$ of volume) and superf used $(0.20 \mathrm{ml} / \mathrm{min})$ with medium gassed with $95 \% \mathrm{O}_{2}-5 \% \mathrm{CO}_{2}$ at $37^{\circ} \mathrm{C}$. The superfusate was collected as $10 \mathrm{~min}$ samples after $40 \mathrm{~min}$ of superfusion $(t=40 \mathrm{~min})$. $\mathrm{Ca}^{2+}$-dependent neurotransmitter release was induced during superfusion by exposing the slices to electrical biphasic block pulses $(1 \mathrm{~Hz}, 10$ $\mathrm{mA}, 2 \mathrm{msec}$ pulses to evoke release of $\left[{ }^{3} \mathrm{H}\right] \mathrm{NA}$, and $1 \mathrm{~Hz}, 30 \mathrm{~mA}, 2 \mathrm{msec}$ pulses to evoke release of $\left[{ }^{3} \mathrm{H}\right] \mathrm{DA}$ ) for $10 \mathrm{~min}$ at $t=50 \mathrm{~min}$ (electrical field stimulation). (-)-Sulpiride or SCH-23390 were added $30 \mathrm{~min}$ before, and DA, SKF-38393, quinpirole, or $\mathrm{N}^{6}$-cyclopentyladenosine (CPA) were added $20 \mathrm{~min}$ before electrical field stimulation. In the experiments investigating the effects of DA on $\left[{ }^{3} \mathrm{H}\right] \mathrm{NA}$ release, $3 \mu \mathrm{M}$ desipramine was present during superfusion to prevent uptake of DA into noradrenergic nerve terminals. Drugs remained present until the end of the experiment. In each experiment, quadruplicate observations were made.

Calculation of release data. The radioactivity remaining at the end of the experiment was extracted from the tissue with $0.1 \mathrm{~N} \mathrm{HCl}$. The radioactivity in superfusion fractions and tissue extracts was determined by liquid scintillation counting. The efflux of radioactivity during each collection period was expressed as a percentage of the amount of radioactivity in the slices at the beginning of the respective collection period. The electrically evoked release of neurotransmitter was calculated by subtracting the spontaneous efflux of radioactivity from the total overflow of radioactivity during stimulation and the next $10 \mathrm{~min}$. A linear decline from the $10 \mathrm{~min}$ interval before to the $20-30 \mathrm{~min}$ after the start of stimulation was assumed for calculation of the spontaneous efflux of radioactivity. The release evoked was expressed as percentage of the content of radioactivity of the slices at the start of the stimulation period. Effects of drugs were calculated as percentages of control and analyzed using one-way ANOVA and, where appropriate, followed by StudentNewman-Keuls tests. Curve fitting was done by nonlinear regression analysis.

Radiochemicals and drugs. $\left[{ }^{3} \mathrm{H}\right]$ Noradrenaline $(39 \mathrm{Ci} / \mathrm{mmol})$ and $\left[{ }^{3} \mathrm{H}\right]$ dopamine $(47 \mathrm{Ci} / \mathrm{mmol})$ were purchased from the Radiochemical Center (Amersham, Buckinghamshire, UK). DA and (-)-sulpiride were purchased from Sigma (St. Louis, MO), and SKF-38393, SCH-23390, quinpirole, GBR-12909, and CPA were purchased from Research Biochemicals (Natick, MA). Desipramine was a gift from Ciba-Geigy (Basel,

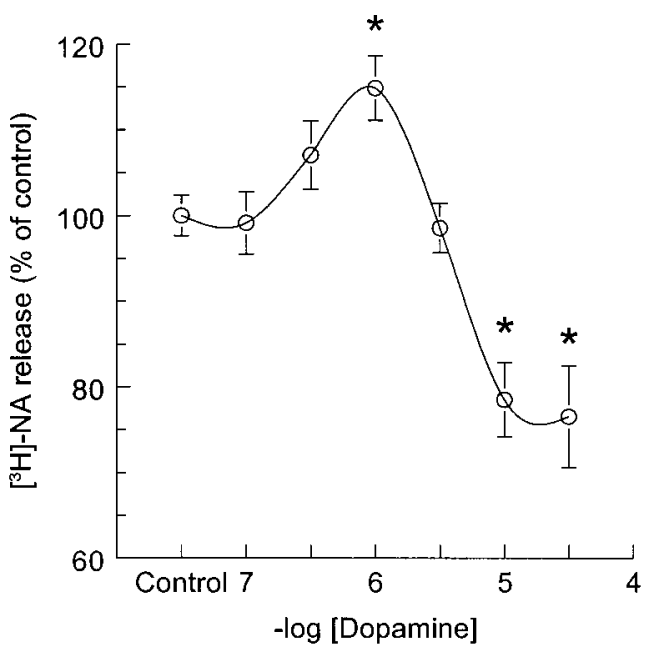

Figure 1. Effect of DA on the electrically evoked release of $\left[{ }^{3} \mathrm{H}\right] \mathrm{NA}$ from superfused slices of rat NAcc. The slices were superfused in the presence of $3 \mu \mathrm{M}$ desipramine to prevent uptake of DA into noradrenergic nerve terminals and were stimulated electrically at $t=50 \mathrm{~min}$ for $10 \mathrm{~min}$. DA was added to the superfusion medium 20 min before depolarization. Control $\left[{ }^{3} \mathrm{H}\right] \mathrm{NA}$ release, in the presence of $3 \mu \mathrm{M}$ desipramine, amounted to $5.8 \pm 0.4 \%$. The data, expressed as percent of control release, represent means \pm SEM of 24 observations. ${ }^{*} p<0.05$ compared with control values (Student-Newman-Keuls test).

Switzerland). (+)-Amphetamine-sulfate was purchased from O.P.G. (Utrecht, The Netherlands) and dissolved in sterile saline.

\section{RESULTS}

\section{DA modulates NAcc NA release through stimulatory D1 and inhibitory D2 receptors}

DA had a biphasic effect on the electrically evoked $\left[{ }^{3} \mathrm{H}\right] \mathrm{NA}$ release $\left(F_{(6,142)}=10.78 ; p<0.001\right)$. A concentration of $0.3 \mu \mathrm{M}$ slightly increased and $1 \mu \mathrm{M}$ significantly increased the evoked release of $\left[{ }^{3} \mathrm{H}\right] \mathrm{NA}$ from superfused rat NAcc slices by $\sim 15 \%$. At a concentration of $3 \mu \mathrm{M}$, DA had no effect on $\left[{ }^{3} \mathrm{H}\right] \mathrm{NA}$ release, and at 10 and $30 \mu \mathrm{M}$, DA appeared to suppress the electrically evoked release of $\left[{ }^{3} \mathrm{H}\right] \mathrm{NA}$ by $20-25 \%$ (Fig. 1 ).

To investigate the contribution of D1 and D2 receptors to the effects of DA on $\left[{ }^{3} \mathrm{H}\right] \mathrm{NA}$ release, selective D1 and D2 agonists and antagonists were applied. The DA D1 agonist SKF-38393 dose-dependently increased electrically evoked $\left[{ }^{3} \mathrm{H}\right] \mathrm{NA}$ release $\left(F_{(5,46)}=7.06 ; p<0.0001\right)$. The maximal effective concentration of SKF-38393 $(1 \mu \mathrm{M})$ caused an increase of $\left[{ }^{3} \mathrm{H}\right] \mathrm{NA}$ release of $\sim 35 \%$ above control (Fig. $2 A$ ). In contrast, the evoked release of $\left[{ }^{3} \mathrm{H}\right] \mathrm{NA}$ was dose-dependently inhibited by the D2 agonist quinpirole $\left(F_{(5,63)}=14.52 ; p<0.0001\right)$; a $40 \%$ inhibition was observed at a concentration of $1 \mu \mathrm{M}$ quinpirole (Fig. $2 B$ ). When the effects of the D1 and D2 antagonists SCH-23390 and (-)sulpiride, respectively, were tested, it appeared that $0.3 \mu \mathrm{M} \mathrm{SCH}-$ 23390 tended to increase $\left[{ }^{3} \mathrm{H}\right] \mathrm{NA}$ release by $\sim 10 \%\left(F_{(1,53)}=\right.$ 3.74; $p=0.06$ ) (Fig. $2 C$ ). ( - -Sulpiride potently increased evoked $\left[{ }^{3} \mathrm{H}\right] \mathrm{NA}$ release, with a $65 \%$ increase above control values observed with $1 \mu \mathrm{M}(-)$-sulpiride $\left(F_{(1,39)}=109.00 ; p<0.0001\right)$ (Fig. 2C).

Consistent with the previous experiment, $1 \mu \mathrm{M}$ SKF-38393 increased electrically evoked $\left[{ }^{3} \mathrm{H}\right] \mathrm{NA}$ release by $33 \%$, whereas 1 $\mu \mathrm{M}$ quinpirole suppressed it by $32 \%$ (Fig. 3, left). In the presence of $0.3 \mu \mathrm{M}$ SCH-23390, the increasing effect of SKF-38393 on $\left[{ }^{3} \mathrm{H}\right] \mathrm{NA}$ release was significantly attenuated, from $33 \%$ in the absence of to $10 \%$ in the presence of respective control values of 

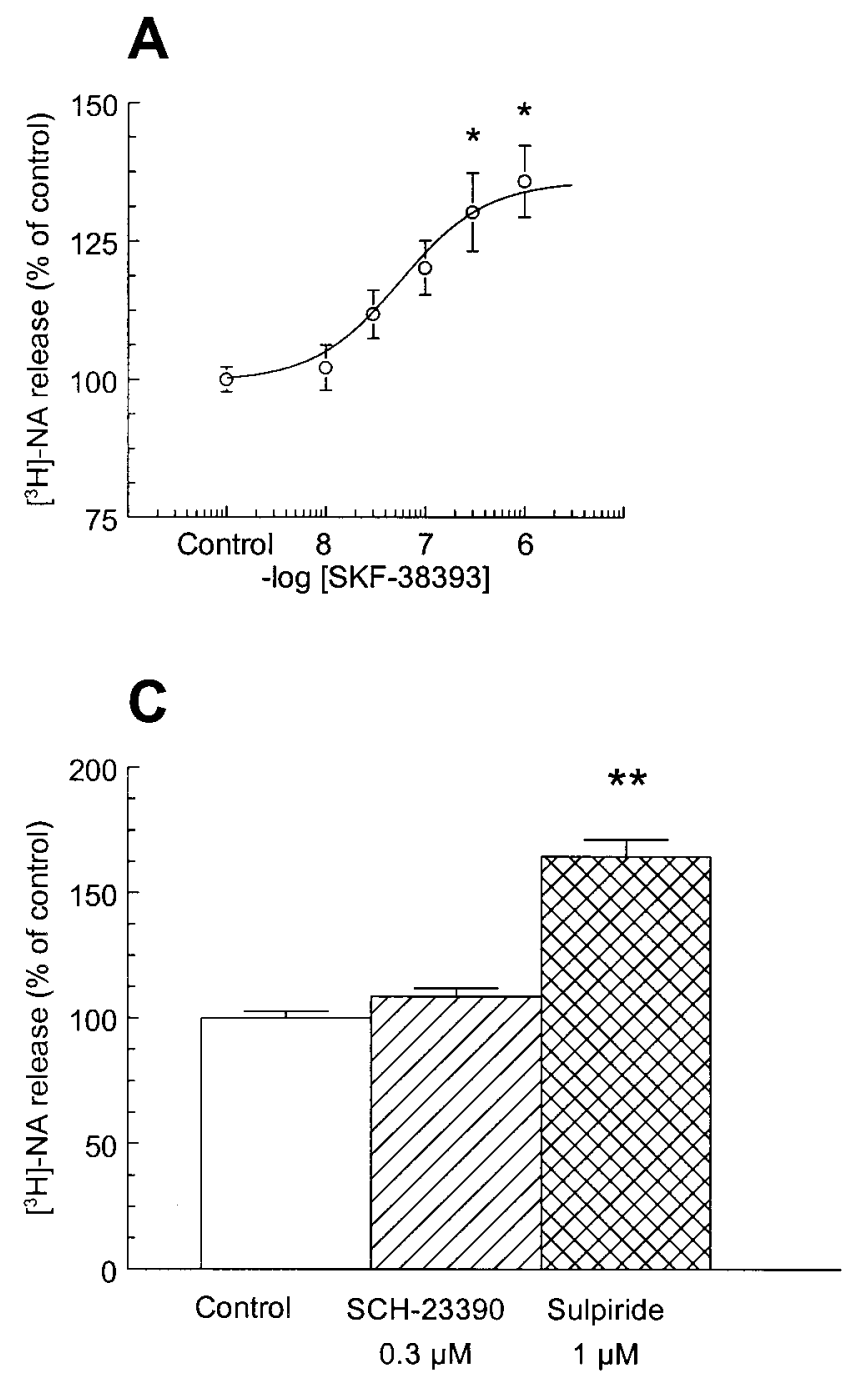

SCH-23390 $\left(F_{(1,37)}=15.53 ; p<0.001\right)$ (Fig. 3, middle). In contrast, $0.3 \mu \mathrm{M}$ SCH-23390 did not at all affect the effect of quinpirole on electrically evoked $\left[{ }^{3} \mathrm{H}\right] \mathrm{NA}$ release; in both the absence and presence of SCH-23390, $1 \mu \mathrm{M}$ quinpirole inhibited $\left[{ }^{3} \mathrm{H}\right] \mathrm{NA}$ release by $32 \%\left(F_{(1,35)}=0.02\right.$; NS) (Fig. 3, middle). Exactly the opposite effect was found with (-)-sulpiride. In a concentration of $1 \mu \mathrm{M},(-)$-sulpiride significantly antagonized the inhibitory effect of quinpirole on evoked $\left[{ }^{3} \mathrm{H}\right] \mathrm{NA}$ release; the decrease in $\left[{ }^{3} \mathrm{H}\right] \mathrm{NA}$ release induced by quinpirole was $32 \%$ in the absence of and $11 \%$ in the presence of $(-)$-sulpiride $\left(F_{(1,26)}=\right.$ 11.65; $p<0.01$ ) (Fig. 3, right). In contrast, the increase in $\left[{ }^{3} \mathrm{H}\right] \mathrm{NA}$ release induced by SKF-38393 was not affected by (-)-sulpiride $\left(F_{(1,27)}=0.28\right.$; NS) (Fig. 3, right).

In the presence of $1 \mu \mathrm{M}(-)$-sulpiride, DA potently increased electrically evoked $\left[{ }^{3} \mathrm{H}\right] \mathrm{NA}$ release $\left(F_{(5,91)}=7.85 ; p<0.0001\right)$. The dose-effect curve of DA was shifted leftward, as apparent from the finding that the lowest concentration of DA to significantly increase NA release was decreased from $1 \mu \mathrm{M}$ to $30 \mathrm{nM}$. In addition, the dose-response curve of DA was also shifted upward, because the maximal effect of DA was increased from $15 \%$ in the absence of to $35 \%$ in the presence of (-)-sulpiride (Fig. 4). It should be noted that the increase in $\left[{ }^{3} \mathrm{H}\right] \mathrm{NA}$ release induced by DA in the presence of $(-)$-sulpiride was of a similar magnitude as that induced by SKF-38393 (compare Figs. 2A, 4). Experiments

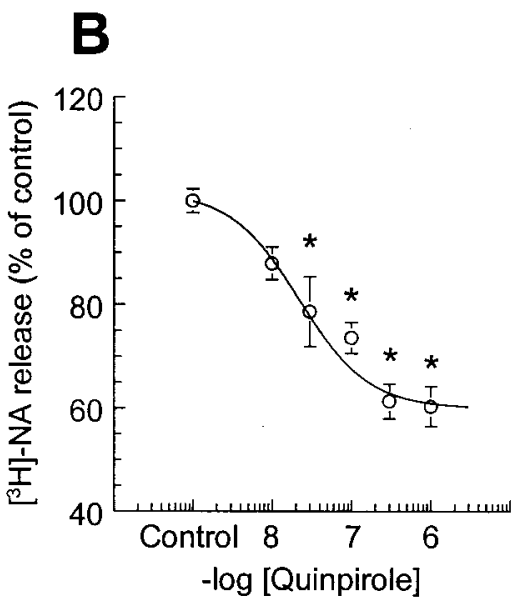

Figure 2. Effects of the D1 agonist SKF-38393 $(A)$, the D2 agonist quinpirole $(B)$, the D1 antagonist SCH-23390 (C; hatched bar), and the D2 antagonist (-)-sulpiride (cross-hatched bar) on the electrically evoked release of $\left[{ }^{3} \mathrm{H}\right] \mathrm{NA}$ from superfused slices of rat NAcc. The slices were superfused and stimulated electrically at $t=50 \mathrm{~min}$ for $10 \mathrm{~min}$. SKF-38393 and quinpirole were added to the superfusion medium at $20 \mathrm{~min}$, and SCH-23390 and (-)-sulpiride were added $30 \mathrm{~min}$ before depolarization. Control $\left[{ }^{3} \mathrm{H}\right] \mathrm{NA}$ release amounted to $4.7 \pm 0.3 \%$. The data, expressed as percent of control release, represent means \pm SEM of 8-28 observations. ${ }^{*} p<0.05$ compared with control values (Student-Newman-Keuls test); ${ }_{* * *} p<0.001$ compared with control values (ANOVA).

on the effects of DA in the presence of SCH-23390 yielded inconsistent results, probably because of the fact that the selectivity of SCH-23390 for D1 over D2 receptors in brain slices is less than 10-fold (Plantjé et al., 1984). Indeed, concentrations of $\mathrm{SCH}-23390>0.3 \mu \mathrm{M}$ caused a marked enhancement of $\left[{ }^{3} \mathrm{H}\right] \mathrm{NA}$ release (data not shown), as observed with $(-)$-sulpiride.

\section{The effects of D1 receptor stimulation on NAcc NA release are not secondary to extracellular conversion of cAMP to adenosine}

Stimulation of D1 receptors enhances adenylate cyclase activity (Stoof and Kebabian, 1984). It has been described recently that certain effects of D1 receptor stimulation are the consequence of extracellular conversion of cAMP to adenosine, which, through stimulation of adenosine A1 receptors, alters neuronal activity (Bonci and Williams, 1996; Harvey and Lacey, 1997). To investigate whether the effect of D1 receptor activation on NAcc $\left[{ }^{3} \mathrm{H}\right] \mathrm{NA}$ release was caused by such a mechanism, the effect of the adenosine A1 agonist CPA was investigated. CPA did not mimic the effect of SKF-38393. On the contrary, CPA appeared to suppress the electrically evoked $\left[{ }^{3} \mathrm{H}\right] \mathrm{NA}$ release by $13 \%$ at a concentration of $0.1 \mu \mathrm{M}$ and by $19 \%$ at a concentration of $1 \mu \mathrm{M}$ $\left(F_{(2,33)}=5.67 ; p<0.01\right.$; data not shown $)$. 
Figure 3. Effect of $0.3 \mu \mathrm{M} \mathrm{SCH}-23390$ (middle) and 1 $\mu \mathrm{M}(-)$-sulpiride (right) on the quinpirole-induced decrease and the SKF-38393-induced increase of electrically evoked $\left[{ }^{3} \mathrm{H}\right] \mathrm{NA}$ release in superfused rat NAcc slices. The slices were superfused and stimulated electrically at $t=50 \mathrm{~min}$ for $10 \mathrm{~min}$. SCH-23390 or (-)sulpiride were added $30 \mathrm{~min}$ before depolarization, and SKF-38393 or quinpirole were added to the superfusion medium at $20 \mathrm{~min}$ before depolarization. Control $\left[{ }^{3} \mathrm{H}\right] \mathrm{NA}$ release amounted to $4.7 \pm 0.3 \%$ of total tissue radioactivity in the absence of antagonists, $5.1 \pm 0.3 \%$ in the presence of SCH-23390, and $7.7 \pm 0.5 \%$ in the presence of (-)-sulpiride, respectively. Data, expressed as percent of respective control release, represent means \pm SEM of 24 observations. Open bars represent $\left[{ }^{3} \mathrm{H}\right] \mathrm{NA}$ release under control conditions, hatched bars represent release in the presence of $1 \mu \mathrm{M}$ quinpirole, and cross-hatched bars represent release in the presence of 1 $\mu \mathrm{M}$ SKF-38393. ${ }^{*} p<0.05 ;{ }^{*} p<0.001$ compared with control values; \#\#p<0.001 compared with same condition without antagonist (ANOVA).

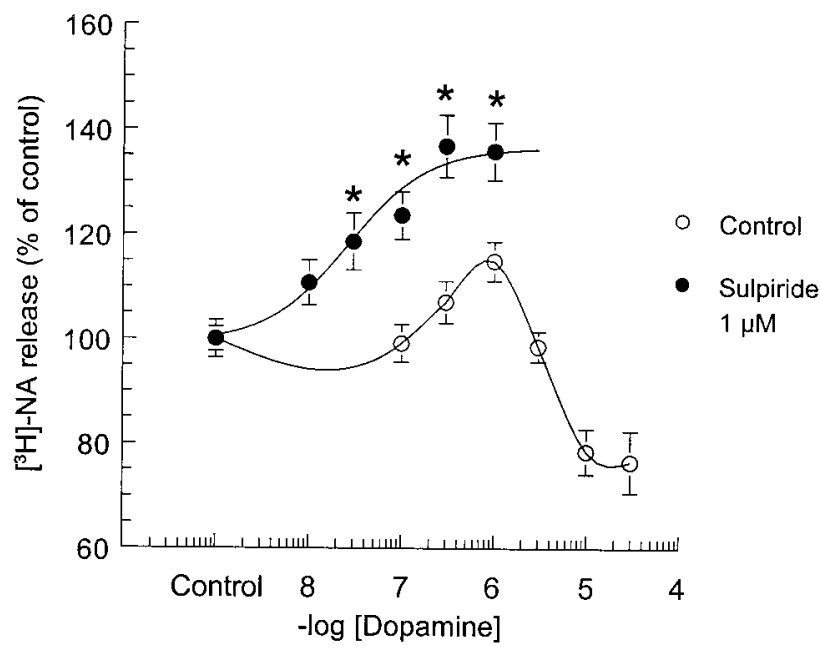

Figure 4. Effect of DA in the absence (compare with Fig. 1; open circles) and in the presence of $1 \mu \mathrm{M}(-)$-sulpiride (closed circles) on the electrically evoked $\left[{ }^{3} \mathrm{H}\right] \mathrm{NA}$ release of superfused rat NAcc slices. The slices were superfused in the presence of $3 \mu \mathrm{M}$ desipramine to prevent uptake of DA into noradrenergic nerve terminals and were stimulated electrically at $t=50 \mathrm{~min}$ for $10 \mathrm{~min}$. (-)-Sulpiride was added to the superfusion medium at $30 \mathrm{~min}$ before depolarization, and DA was added at $20 \mathrm{~min}$ before depolarization. Control $\left[{ }^{3} \mathrm{H}\right] \mathrm{NA}$ release amounted to $5.8 \pm 0.4 \%$ of total tissue radioactivity in the absence of and $7.2 \pm 0.5 \%$ in the presence of $(-)$-sulpiride, respectively. Data, expressed as percent of control release, represent means \pm SEM of 24 observations. ${ }^{*} p<0.05$ compared with control values in the presence of $(-)$-sulpiride (StudentNewman-Keuls test).

\section{DAergic regulation of NA release does not occur within medial prefrontal cortex and amygdala}

Regulation by DA of NA release has been reported previously to occur in the hypothalamus (Misu et al., 1985) and hippocampus (Jackisch et al., 1985), but, in those areas only a D2-mediated inhibition of NA release was found. To investigate whether the opposite regulation of NA release by $\mathrm{D} 1$ and $\mathrm{D} 2$ receptors also occurred in other limbic areas, we studied the effects of SKF38393 and quinpirole on NA release in slices of medial prefrontal

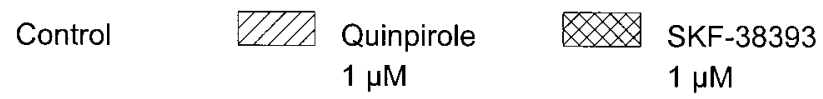

$1 \mu \mathrm{M}$

$1 \mu \mathrm{M}$

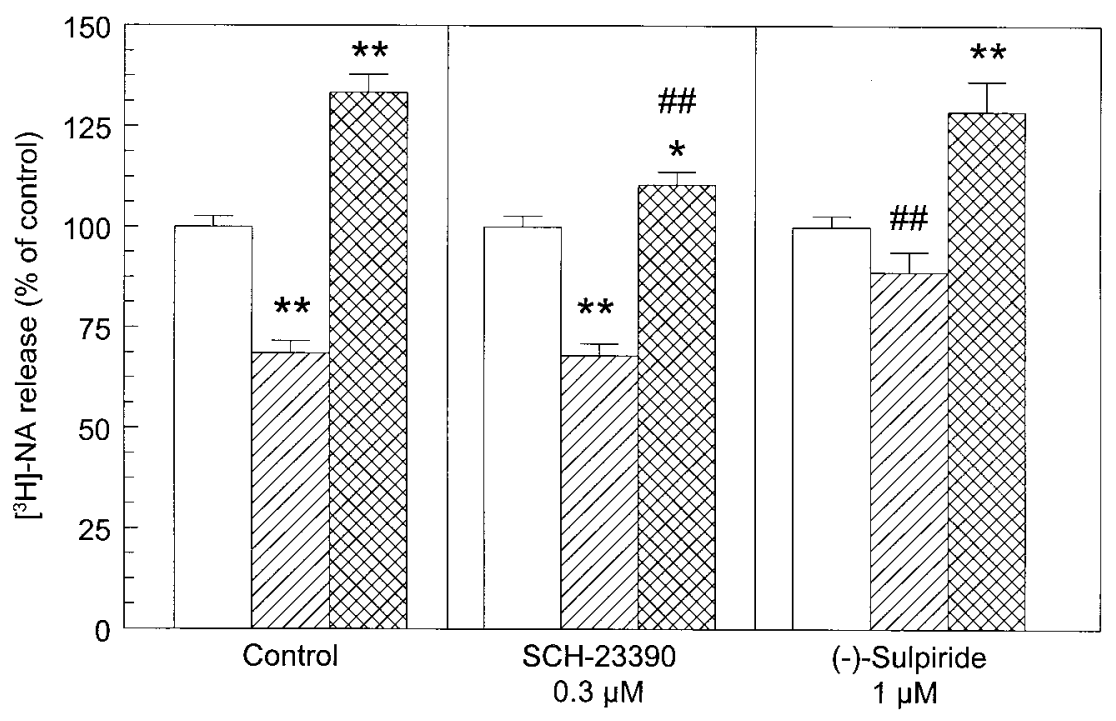

Control LDA Quinpirole $\$$ SKF-38393 $1 \mu \mathrm{M} \quad 1 \mu \mathrm{M}$

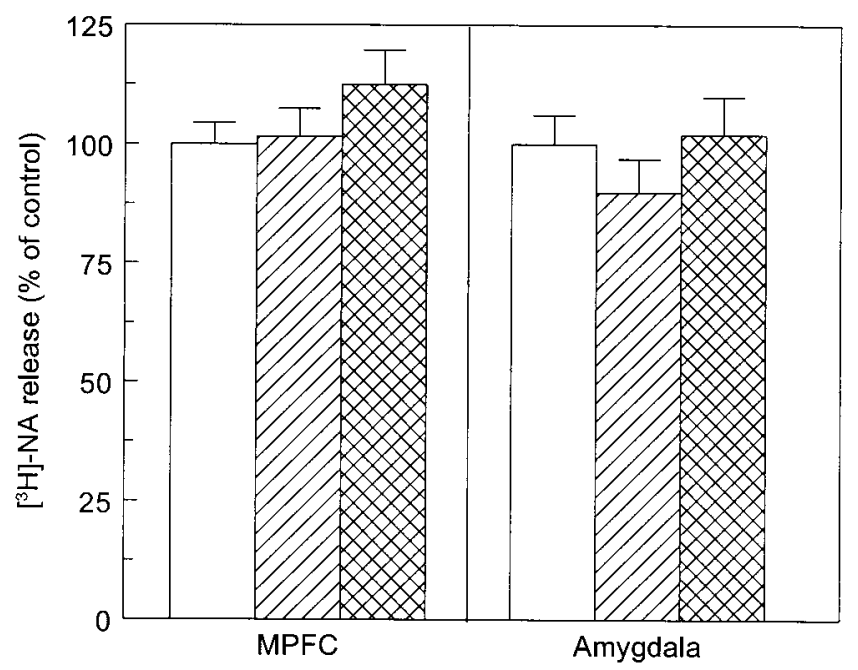

Figure 5. Effects of SKF-38393 $(1 \mu \mathrm{M})$ and quinpirole $(1 \mu \mathrm{M})$ on the electrically evoked release of $\left[{ }^{3} \mathrm{H}\right] \mathrm{NA}$ from superfused slices of rat medial prefrontal cortex (MPFC; left) or amygdala (right). The slices were superfused and stimulated electrically at $t=50 \mathrm{~min}$ for $10 \mathrm{~min}$. SKF-38393 and quinpirole were added to the superfusion medium at $20 \mathrm{~min}$ before depolarization. Control $\left[{ }^{3} \mathrm{H}\right] \mathrm{NA}$ release amounted to $4.1 \pm 0.3 \%$ in medial prefrontal cortex slices and $3.0 \pm 0.2 \%$ in amygdala slices. Data, expressed as percent of control release, represent means \pm SEM of 11-12 observations. Open bars represent $\left[{ }^{3} \mathrm{H}\right] \mathrm{NA}$ release under control conditions, hatched bars represent release in the presence of $1 \mu \mathrm{M}$ quinpirole, and cross-hatched bars represent release in the presence of $1 \mu \mathrm{M}$ SKF-38393.

cortex and amygdala. In slices of medial prefrontal cortex, $1 \mu \mathrm{M}$ SKF-38393 slightly, but not significantly (12\% above control), increased electrically evoked $\left[{ }^{3} \mathrm{H}\right] \mathrm{NA}$ release $\left(F_{(1,23)}=2.17\right.$; NS). Quinpirole, at a concentration of $1 \mu \mathrm{M}$, did not affect medial prefrontal cortex $\left[{ }^{3} \mathrm{H}\right] \mathrm{NA}$ release $\left(F_{(1,23)}=0.05\right.$; NS) (Fig. 5, left $)$. In rat amygdala slices, SKF-38393 $(1 \mu \mathrm{M})$ did not at all affect electrically evoked $\left[{ }^{3} \mathrm{H}\right] \mathrm{NA}$ release $\left(F_{(1,23)}=0.04\right.$; NS), whereas 

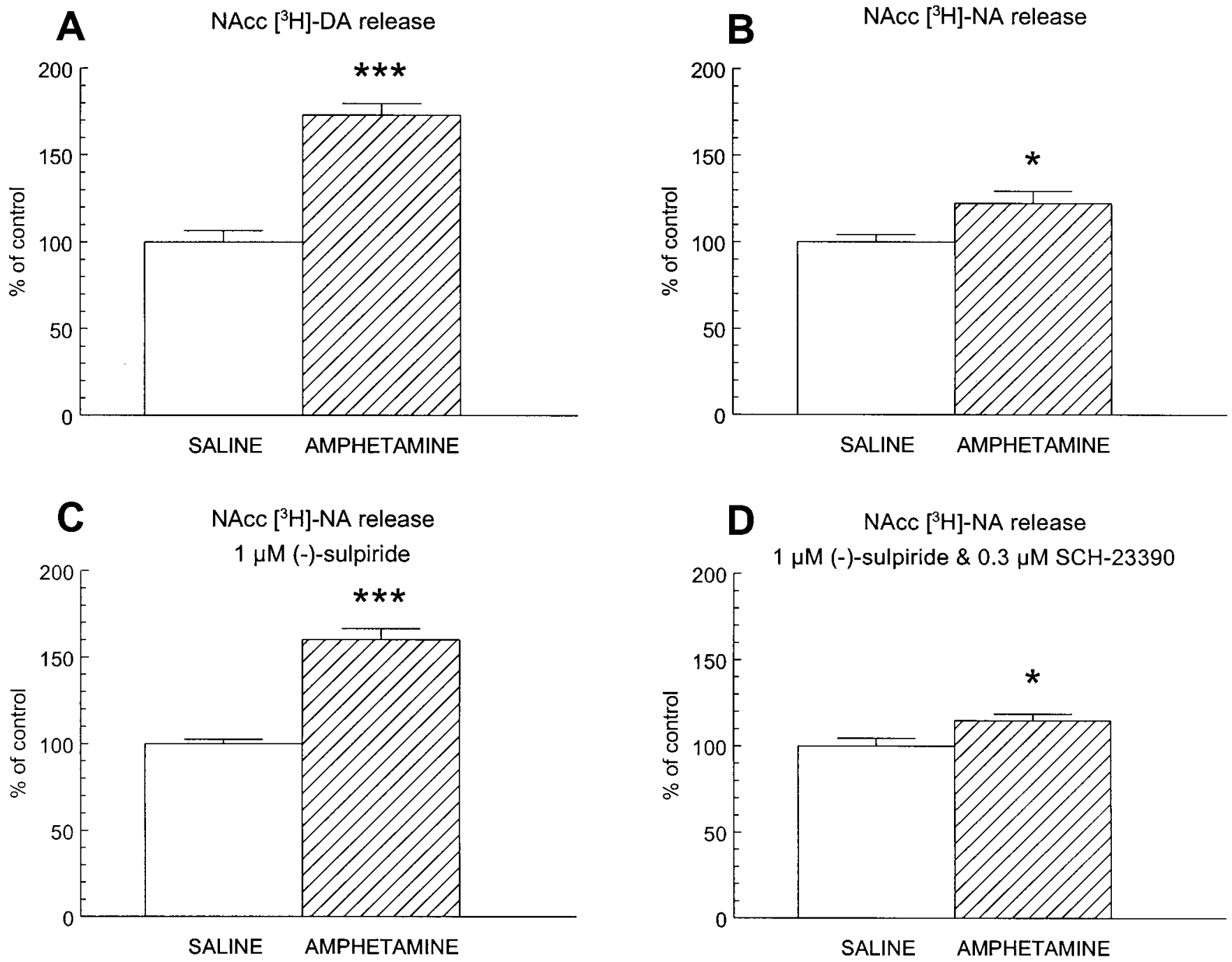

Figure 6. A, Electrically evoked release of [ $\left.{ }^{3} \mathrm{H}\right] \mathrm{DA}$ from superfused NAcc slices of rats pretreated with amphetamine $(5 \times 2.5 \mathrm{mg} / \mathrm{kg}$, i.p.; hatched bar $)$ or saline (open bar) $3 \mathrm{~d}$ after treatment. $\left[{ }^{3} \mathrm{H}\right] \mathrm{DA}$ release amounted to $1.0 \pm 0.1 \%$ in slices of saline-pretreated rats. $B$, Electrically evoked release of $\left[{ }^{3} \mathrm{H}\right] \mathrm{NA}$ from superfused NAcc slices of rats pretreated with amphetamine $(5 \times 2.5 \mathrm{mg} / \mathrm{kg}$, i.p.; hatched bar $)$ or saline (open bar) $3 \mathrm{~d}$ after treatment. $\left[{ }^{3} \mathrm{H}\right] \mathrm{NA}$ release amounted to $4.1 \pm 0.2 \%$ in slices of saline-pretreated rats. $C$, Electrically evoked release of [ $\left.{ }^{3} \mathrm{H}\right] \mathrm{NA}$ from superfused NAcc slices of rats pretreated with amphetamine $(5 \times 2.5 \mathrm{mg} / \mathrm{kg}$, i.p.; hatched bar $)$ or saline (open bar) in the presence of $1 \mu \mathrm{M}(-)$-sulpiride $3 \mathrm{~d}$ after treatment. [ ${ }^{3} \mathrm{H}$ ] NA release amounted to $6.0 \pm 0.3 \%$ in slices of saline-pretreated rats. $D$, Electrically evoked release of $\left[{ }^{3} \mathrm{H}\right] \mathrm{NA}$ from superfused NAcc slices of rats pretreated with amphetamine $(5 \times 2.5 \mathrm{mg} / \mathrm{kg}$, i.p.; hatched bar) or saline (open bar) in the presence of $1 \mu \mathrm{M}(-)$-sulpiride and $0.3 \mu \mathrm{M} \mathrm{SCH}-233903 \mathrm{~d}$ after treatment. $\left[{ }^{3} \mathrm{H}\right] \mathrm{NA}$ release amounted to $7.8 \pm 0.4 \%$ in slices of saline-pretreated rats. NAcc slices were superfused and stimulated electrically at $t=50 \mathrm{~min}$ for $10 \mathrm{~min}$. (-)-Sulpiride and SCH-23390 were added to the superfusion medium at 30 min before depolarization. Note that the data are expressed as percent of respective control release in slices of saline-pretreated rats. The basic effects of (-)-sulpiride and SCH-23390 (Fig. $2 C$ ) are therefore not shown. Data represent means \pm SEM of $8-23$ observations. ${ }^{*} p<0.05$; ${ }^{* *} p<0.0001$ compared with saline pretreatment (ANOVA).

quinpirole $(1 \mu \mathrm{M})$ caused a slight $(12 \%)$ nonsignificant inhibition of evoked $\left[{ }^{3} \mathrm{H}\right] \mathrm{NA}$ release $\left(F_{(1,22)}=1.19 ; \mathrm{NS}\right)$ (Fig. 5, right).

\section{Altered modulation of NAcc NA release by DA in slices of amphetamine-pretreated rats}

In NAcc slices of amphetamine-pretreated animals, the electrically evoked release of $\left[{ }^{3} \mathrm{H}\right] \mathrm{DA}$ was augmented by $73 \%\left(F_{(1,15)}=\right.$ 61.25; $p<0.0001$ ) (Fig. $6 A$ ), and the electrically evoked $\left[{ }^{3} \mathrm{H}\right] \mathrm{NA}$ release was increased by $22 \%\left(F_{(1,23)}=7.34 ; p<0.05\right)$ (Fig. $\left.6 B\right)$. Whereas in slices of saline-pretreated rats $1 \mu \mathrm{M}(-)$-sulpiride caused a $46 \%$ increase in evoked NAcc $\left[{ }^{3} \mathrm{H}\right] \mathrm{NA}$ release (data not shown, but see Fig. $2 C$ ), in slices of amphetamine-pretreated rats, $1 \mu \mathrm{M}(-)$-sulpiride enhanced evoked $\left[{ }^{3} \mathrm{H}\right] \mathrm{NA}$ release by $92 \%$. Thus, in the presence of $1 \mu \mathrm{M}(-)$-sulpiride, the relative enhance- ment of evoked $\left[{ }^{3} \mathrm{H}\right] \mathrm{NA}$ release in slices of amphetaminepretreated rats was $60 \%\left(F_{(1,45)}=74.37 ; p<0.0001\right)$ (Fig. 6C) compared with $22 \%$ in the absence of sulpiride (Fig. $6 B$ ), indicating enhanced D2 receptor activation in slices of amphetaminepretreated rats. SCH-23390 $(0.3 \mu \mathrm{M})$ slightly enhanced evoked $\left[{ }^{3} \mathrm{H}\right] \mathrm{NA}$ release in NAcc slices of saline-pretreated animals, but in slices of amphetamine-pretreated rats, $\mathrm{SCH}-23390$ suppressed [ ${ }^{3} \mathrm{H}$ ]NA release by $20 \%$ (data not shown). However, these data cannot be interpreted unambiguously because $0.3 \mu \mathrm{M} \mathrm{SCH}-23390$ may be expected to partially block D2 receptors (Plantjé et al., 1984). Therefore, the effect of SCH-23390 was investigated in the presence of $1 \mu \mathrm{M}(-)$-sulpiride. Interestingly, under circumstances of D2 receptor blockade, $0.3 \mu \mathrm{M}$ SCH-23390 appeared to 
diminish the increase in NAcc $\left[{ }^{3} \mathrm{H}\right] \mathrm{NA}$ release after previous amphetamine treatment to $15 \%\left(F_{(1,22)}=6.20 ; p<0.05\right)$ (Fig. $6 D)$. Thus, SCH-23390 almost abolished the increase in electrically evoked $\left[{ }^{3} \mathrm{H}\right] \mathrm{NA}$ release observed in slices of rats preexposed to amphetamine.

\section{DISCUSSION}

The present data demonstrate that NA release in the rat NAcc is under the opposing influence of stimulatory DA D1 and inhibitory DA D2 receptors. These NA release-modulatory DA receptors are presumably localized on nerve terminals of NA neurons originating in the NTS (Delfs et al., 1998). Although occurrence of presynaptic receptors on central nerve terminals has indeed been demonstrated (Fisher et al., 1994; Sesack et al., 1994; Hersch et al., 1995), the involvement of indirect or transsynaptic regulation of neurotransmitter release cannot be excluded, even in superfused brain slices. It is therefore possible that DA indirectly affects NAcc NA release through modulation of excitatory or inhibitory neurotransmission. In this respect, electrophysiological experiments have shown that, in the NAcc, stimulation of presynaptic D1 receptors depresses both inhibitory and excitatory transmission (Pennartz et al., 1992; Harvey and Lacey, 1996; Nicola and Malenka, 1997, 1998), whereas activation of presynaptic D2 receptors suppresses excitatory transmission (O'Donnell and Grace, 1994). Microdialysis studies have shown that D1 receptor stimulation actually enhances NAcc GABA release, whereas D2 receptor stimulation appears to inhibit glutamate release in the NAcc (Kalivas and Duffy, 1997). Thus, some of these data seem to fit with the present observations of stimulatory effects of D1 receptors and inhibitory effects of D2 receptor stimulation, but others do not. The present data can therefore not be explained solely on the basis of DA effects on excitatory and inhibitory inputs into the NAcc rather than direct DA effects on NA varicosities. Neurotransmission-modulatory effects of D1 receptor stimulation may also be indirectly mediated by the release of adenosine (Bonci and Williams, 1996; Harvey and Lacey, 1997), but the selective adenosine A1 receptor agonist CPA appeared not to mimic the stimulatory effects of D1 receptor stimulation but even slightly decreased NAcc $\left[{ }^{3} \mathrm{H}\right] \mathrm{NA}$ release. This suggests that, although release-inhibitory adenosine A1 receptors may be present on NAcc NA nerve terminals, the stimulatory effect of D1 receptor activation is not mediated indirectly through activation of adenosine receptors. Together, although possible indirect effects of D1 and D2 receptor stimulation cannot be ruled out, it is most likely that the release-modulatory DA receptors are located on NAcc NA varicosities.

With regard to the tonic activation of these DA receptors, the D2 antagonist (-)-sulpiride strongly increased NAcc NA release, whereas the D1 antagonist SCH-23390 did not reduce NA release. Thus, released endogenous DA tonically inhibits NAcc NA release through stimulation of D2 receptors, whereas the stimulatory D1 receptors are not activated under the present in vitro conditions. Because one of our previous studies showed that, in superfused rat striatal slices, exogenous and endogenous DA displays an identical apparent affinity to D1 and D2 receptors (Schoffelmeer et al., 1994), differences in apparent affinity for DA cannot account for these findings. A more likely explanation is that D1 and D2 receptors are differentially located on or near NA nerve terminals. We hypothesize that D2 receptors are located near active zones formed by DA and NA nerve terminals, whereas D1 receptors are located more distal from the site of DA release (Fig. 7, top). Indeed, such a differential localization of D1 and D2 receptors is supported by ultrastructural studies indicating that NAcc D1 receptors are mainly localized extrasynaptically (Smiley et al., 1994; Hersch et al., 1995; Caillé et al., 1996), whereas D2 receptors can be found near DAergic nerve terminals (Fisher et al., 1994; Sesack et al., 1994; Hersch et al., 1995; Delle Donne et al., 1996). Interestingly, voltammetric measurements of synaptic DA efflux showed that extrasynaptic DA neurotransmission occurs in the NAcc (Garris et al., 1994) and that excitatory signals can be conveyed by extrasynaptic D1 receptors activated by released DA, diffusing up to $12 \mu \mathrm{M}$ away from release sites (Gonon, 1997). In the case of DA modulation of NAcc NA release, this would imply that DA released from mesolimbic neurons preferentially interacts with $\mathrm{D} 2$ receptors, located in the vicinity of the site of release. D1 receptors, located further away, might be stimulated in case of higher rates of release and/or during later phases of neurotransmission by DA that has diff used away from the synapse (Fig. 7, bottom). The biphasic effects of exogenously applied DA, activating both D1 and D2 receptors (Schoffelmeer et al., 1994), could be the consequence of such a different role of D1 and D2 receptors. For instance, when low concentrations of exogenous DA are applied, the possible inhibitory effect of this exogenous DA could be masked by the tonic D2 receptor-mediated inhibition of NA release, causing the D1 receptor-mediated increasing effect to prevail (Fig. 1). It is also worth noting that, in the presence of $(-)$-sulpiride when DA will only stimulate D1 receptors, the dose-response curve of DA was shifted upward, as well as leftward, closely resembling the doseresponse curve of SKF-38393 (compare Figs. 4, 2A).

Both the medial prefrontal cortex and the amygdala represent limbic brain areas that, similar to the NAcc, receive dense DA and NA innervations (Ungerstedt, 1971; Moore and Bloom, 1978, 1979; Le Moal and Simon, 1991). However, [ $\left.{ }^{3} \mathrm{H}\right] \mathrm{NA}$ release in slices of these areas does not seem to be modulated by DA. A possible explanation for this difference is that the NA projection to the NAcc originates mainly in the NTS (Delfs et al., 1998), whereas medial prefrontal cortex and amygdala receive a NA innervation from the locus ceruleus (Ungerstedt, 1971; Moore and Bloom, 1979). Similar phenomena have been observed with regard to the modulation of NA release by opioid receptors, which also seems to differ between different regions of origin (Heijna et al., 1991). The present data add to a growing body of evidence that NAcc NA release may be modulated in a unique manner. For instance, we have shown recently that, unlike in most other brain areas receiving NA input, NAcc NA release is not under the inhibitory influence of $\alpha_{2}$-autoreceptors (Schoffelmeer et al., 1998).

The physiological relevance of the opposite regulation of NAcc NA release by D1 and D2 receptors remains to be elucidated. Coordinated activity of NAcc NA and DA neurotransmission may be necessary for adequate processing of motivational, visceral, and autonomic stimuli into behavioral responses (Le Moal and Simon, 1991; Phillips et al., 1991; Salamone, 1994; Schultz et al., 1997; Delfs et al., 1998). The subtle interregulation of NAcc NA and DA release therefore suggests the existence of a catecholaminergic fine-tuning mechanism modulating the generation of adaptive behavioral responses. In this respect, it is of interest to note that recent electrophysiological experiments have shown that, while in the NAcc DA, via D1 receptors, inhibits both excitatory and inhibitory transmission; NA, via $\alpha$-receptors only inhibited excitatory, but not inhibitory, transmission (Nicola and 


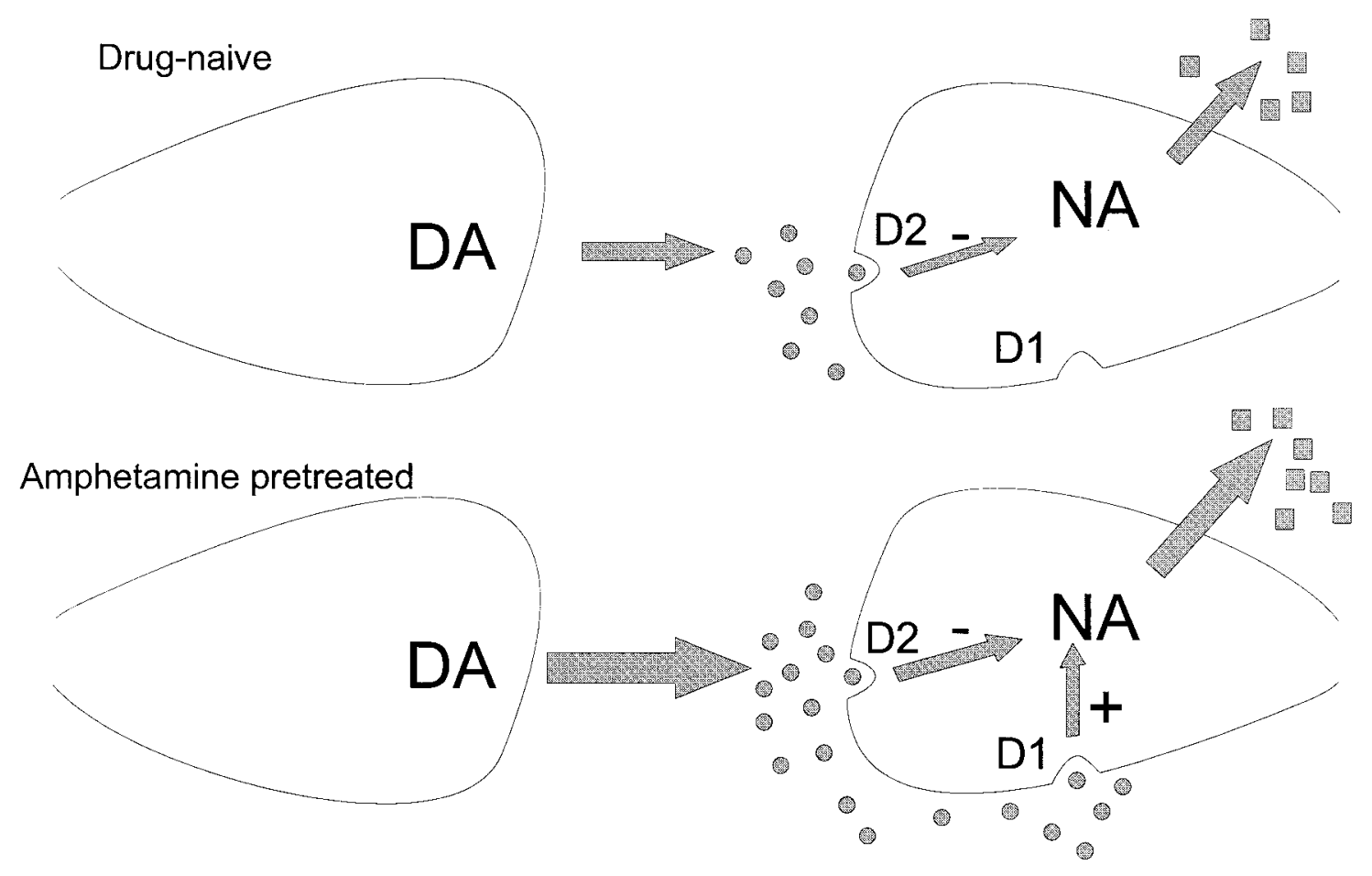

Figure 7. Hypothetical model of the modulation of NAcc NA release by DA and alterations therein after repeated exposure to amphetamine. DA ( $)$, released from mesolimbic projections, is able to modulate NA (ם) release in two directions: stimulation through D1 receptors and inhibition through D2 receptors. In drug-naive animals, released DA will tonically inhibit NA release via stimulation of inhibitory D2 receptors, whereas D1 receptors do not seem to be involved in the tonic DAergic regulation of NA release. We suggest that this is because of differential localization of D1 and D2 receptors on or near NA varicosities (top). In the case of enhanced DA overflow (e.g., caused by repeated exposure to amphetamine in vivo), the D2 receptor-mediated suppression of NA release will increase. In addition, excess DA will diff use further away from the site of release and stimulate D1 receptors as well, causing NA release to become enhanced (bottom).

Malenka, 1998). This suggests that the balance of DA and NA neurotransmission in the NAcc might determine whether excitatory or inhibitory input into NAcc neurons will prevail. In addition, the entwinement of NAcc DA and NA systems could be involved in certain phenomena associated with drug abuse, such as psychostimulant sensitization and opiate withdrawal (Harris and Aston-Jones, 1994). In parallel to the effects on NAcc NA release described here, administration of D2 agonists into the NAcc shell has been shown to inhibit, and administration of a D1 agonist has been shown to enhance naloxone-evoked opiate withdrawal effects, whereas an intra-NAcc D2 antagonist appeared to evoke opiate withdrawal phenomena (Harris and Aston-Jones, 1994). Because increased NA activity accompanies opiate withdrawal (Akaoka and Aston-Jones, 1991; De Vries et al., 1993), it is likely that the effects of intra-NAcc-applied DAergic drugs on opiate withdrawal involve modulation of NAcc NA release.

In NAcc slices of amphetamine-pretreated rats, the electrically evoked release of both $\left[{ }^{3} \mathrm{H}\right] \mathrm{NA}$ and $\left[{ }^{3} \mathrm{H}\right] \mathrm{DA}$ was enhanced. Moreover, the increase in $\left[{ }^{3} \mathrm{H}\right] \mathrm{NA}$ release induced by $\mathrm{D} 2$ receptor blockade with (-)-sulpiride was enhanced, indicating an increase in the tonic D2-mediated suppression of NA release. Remarkably, SCH-23390 primarily antagonized this augmentation of NAcc NA release induced by amphetamine preexposure. These data indicate that, under conditions of different dopaminergic tone in the accumbens, NA release is differentially regulated by DA receptors. In addition, they are consistent with our hypothesis that D1 receptors represent extrasynaptic receptors, particularly stimulated under conditions of increased DA release. Thus, under circumstances of moderate DA tone, released DA, stimulating D2 receptors, tonically suppresses NAcc NA release, whereas extrasynaptically located D1 receptors play a less prominent role in the regulation of NA release (Fig. 7, top). When DA tone is increased, such as in amphetamine-pretreated rats, enhanced DA release from mesolimbic terminals increases the tonic D2-receptor-mediated suppression of NA release. In addition, augmented DA release will also stimulate extrasynaptic D1 receptors, resulting in a net increase in NAcc NA release (Fig. 7, bottom). Assuming that the balance between NAcc DA and NA activity is relevant for the formation of adequate adaptive behavioral responses, this amphetamine-induced disbalance in catecholamine neurotransmission could represent a substrate for the distorted motivational and affective behaviors characteristic for drug-induced addiction and psychosis.

\section{REFERENCES}

Akaoka H, Aston-Jones G (1991) Opiate withdrawal-induced hyperactivity of locus coeruleus neurons is substantially mediated by augmented excitatory amino acid input. J Neurosci 11:3830-3839.

Amalric M, Koob GF (1993) Functionally selective neurochemical afferents and efferents of the mesocorticolimbic and nigrostriatal dopamine system. Prog Brain Res 99:209-226.

Berridge CW, Stratford TL, Foote SL, Kelley AE (1997) Distribution of dopamine $\beta$-hydroxylase-like immunoreactive fibers within the shell subregion of the nucleus accumbens. Synapse 27:230-241.

Bonci A, Williams JT (1996) A common mechanism mediates long-term changes in synaptic transmission after chronic cocaine and morphine. Neuron 16:631-639.

Caillé I, Dumartin B, Bloch B (1996) Ultrastructural localization of D1 dopamine receptor immunoreactivity in rat striatonigral neurons and its relation with dopaminergic innervation. Brain Res 730:17-31. 
De Vries TJ, Tjon Tien Ril GHK, Van der Laan JW, Mulder AH, Schoffelmeer ANM (1993) Chronic exposure to morphine and naltrexone induces changes in catecholaminergic neurotransmission in rat brain without altering $\mu$-opioid receptor sensitivity. Life Sci 52:1685-1693.

Delfs JM, Schreiber L, Kelley AE (1990) Microinjection of cocaine into the nucleus accumbens elicits locomotor activation in the rat. J Neurosci 10:303-310.

Delfs JM, Zhu Y, Druhan JP, Aston-Jones GS (1998) Origin of noradrenergic afferents to the shell subregion of the nucleus accumbens: anterograde and retrograde tract-tracing studies in the rat. Brain Res 806:127-140.

Delle Donne KT, Sesack SR, Pickel VM (1996) Ultrastructural immunocytochemical localization of neurotensin and the dopamine $\mathrm{D}_{2}$ receptor in the rat nucleus accumbens. J Comp Neurol 371:552-566.

Di Chiara G, Imperato A (1988) Drugs abused by humans preferentially increase synaptic dopamine concentrations in the mesolimbic system of freely moving rats. Proc Natl Acad Sci USA 85:5274-5278.

Dickinson SL, Gadie B, Tulloch IF (1988) $\alpha_{1}$ - and $\alpha_{2}$-Adrenoceptor antagonists differentially influence locomotor and stereotyped behaviour induced by $d$-amphetamine and apomorphine in the rat. Psychopharmacology 96:521-527.

Fisher RS, Levine MS, Sibley DR, Ariano MA (1994) $\mathrm{D}_{2}$ dopamine receptor protein location: Golgi impregnation-gold toned and ultrastructural analysis of the rat neostriatum. J Neurosci Res 38:551-564.

Garris PA, Ciolkowski EL, Pastore P, Wightman RM (1994) Efflux of dopamine from the synaptic cleft in the nucleus accumbens of rat brain. J Neurosci 14:6084-6093.

Gonon F (1997) Prolonged and extrasynaptic excitatory action of dopamine mediated by D1 receptors in the rat striatum in vivo. J Neurosci 17:5972-5978.

Harris GC, Aston-Jones G (1994) Involvement of D2 dopamine receptors in the nucleus accumbens in the opiate withdrawal syndrome. Nature 371:155-157.

Harris GC, Hedaya MA, Pan W-J, Kalivas P (1996) $\beta$-Adrenergic antagonism alters the behavioral and neurochemical responses to cocaine. Neuropsychopharmacology 14:195-204.

Harvey J, Lacey MG (1996) Endogenous and exogenous dopamine depress EPSCs in rat nucleus accumbens in vitro via $\mathrm{D}_{1}$ receptor activation. J Physiol (Lond) 492:143-154.

Harvey J, Lacey MG (1997) A postsynaptic interaction between dopamine $\mathrm{D}_{1}$ and NMDA receptors promotes presynaptic inhibition in the rat nucleus accumbens via adenosine release. J Neurosci 17:5271-5280.

Heijna MH, Padt M, Hogenboom F, Schoffelmeer ANM, Mulder AH (1991) Opioid-receptor-mediated inhibition of $\left[{ }^{3} \mathrm{H}\right]$ dopamine but not $\left[{ }^{3} \mathrm{H}\right]$ noradrenaline release from rat mediobasal hypothalamus slices. Neuroendocrinology 54:118-126.

Hersch SM, Ciliax BJ, Gutekunst C-A, Rees HD, Heilman CJ, Yung KKL, Bolam JP, Ince E, Yi H, Levey AI (1995) Electron microscopic analysis of D1 and D2 dopamine receptor proteins in the dorsal striatum and their synaptic relationships with motor corticostriatal afferents. J Neurosci 15:5222-5237.

Jackisch R, Moll S, Feuerstein TJ, Hertting G (1985) Dopaminergic modulation of hippocampal noradrenaline release: evidence for $\alpha_{2}$ antagonistic effects of some dopamine receptor agonists and antagonists. Naunyn Schmiedebergs Arch Pharmacol 330:105-113.

Kalivas PW, Duffy P (1997) Dopamine regulation of extracellular glutamate in the nucleus accumbens. Brain Res 761:173-177.

Kalivas PW, Stewart J (1991) Dopamine transmission in the initiation and expression of drug- and stress-induced sensitization of motor activity. Brain Res Rev 16:223-244.

Kalivas PW, Churchill L, Klitenick MA (1993) The circuitry mediating the translation of motivational stimuli into adaptive motor responses. In: Limbic motor circuits and neuropsychiatry (Kalivas PW, Barnes CD, eds), pp 237-287. Boca Raton, FL: CRC.

Kelly PH, Seviour PW, Iversen SD (1975) Amphetamine and apomorphine responses in the rat following 6-OHDA lesions of the nucleus accumbens septi and corpus striatum. Brain Res 94:507-522.

Koob GF (1992) Drugs of abuse: anatomy, pharmacology and function of reward pathways. Trends Pharmacol Sci 13:177-184.

Le Moal M, Simon H (1991) Mesocorticolimbic dopaminergic network: functional and regulatory roles. Physiol Rev 71:155-234.
McKittrick CR, Abercrombie ED (1997) Identification of nucleus accumbens subfields in vivo by extracellular catecholamine profile: predominant role for norepinephrine in shell. Soc Neurosci Abstr 23:2040.

Misu Y, Goshima Y, Ueda H, Kubo T (1985) Presynaptic inhibitory dopamine receptors on noradrenergic nerve terminals: analysis of biphasic actions of dopamine and apomorphine on the release of endogenous norepinephrine in rat hypothalamic slices. J Pharmacol Exp Ther 235:771-777.

Mogenson GJ (1987) Limbic-motor integration. In: Progress in psychobiology and physiological psychology (Epstein AN, Morrison AR, eds), pp 117-170. New York: Academic.

Moore RY, Bloom FE (1978) Central catecholamine neuron systems: anatomy and physiology of the dopamine systems. Annu Rev Neurosci 1:129-169.

Moore RY, Bloom FE (1979) Central catecholamine neuron systems: anatomy and physiology of the norepinephrine and epinephrine systems. Annu Rev Neurosci 2:113-168.

Nestby P, Vanderschuren LJMJ, De Vries TJ, Hogenboom F, Wardeh G, Mulder AH, Schoffelmeer ANM (1997) Ethanol, like psychostimulants and morphine, causes long-lasting hyperreactivity of dopamine and acetylcholine neurons of rat nucleus accumbens: possible role in behavioural sensitization. Psychopharmacology 133:69-76.

Nicola SM, Malenka RC (1997) Dopamine depresses excitatory and inhibitory synaptic transmission by distinct mechanisms in the nucleus accumbens. J Neurosci 17:5697-5710.

Nicola SM, Malenka RC (1998) Modulation of synaptic transmission by dopamine and norepinephrine in ventral but not dorsal striatum. J Neurophysiol 79:1768-1776.

Nurse B, Russell VA, Taljaard JJ (1984) $\alpha_{2^{-}}$and $\beta$-Adrenoceptor agonists modulate $\left[{ }^{3} \mathrm{H}\right]$ dopamine release from rat nucleus accumbens slices: implications for research into depression. Neurochem Res 9:1231-1238.

O'Donnell P, Grace AA (1994) Tonic $\mathrm{D}_{2}$-mediated attenuation of cortical excitation in nucleus accumbens neurons recorded in vitro. Brain Res 634:105-112.

Paxinos G, Watson C (1986) The rat brain in stereotaxic coordinates. Orlando, FL: Academic.

Pennartz CMA, Dolleman-Van der Weel MJ, Kitai ST, Lopes da Silva FH (1992) Presynaptic dopamine D1 receptors attenuate excitatory and inhibitory limbic inputs into the shell region of the rat nucleus accumbens studied in vitro. J Neurophysiol 67:1325-1334.

Phillips AG, Pfaus JG, Blaha CD (1991) Dopamine and motivated behavior: insights provided by in vivo analyses. In: The mesolimbic dopamine system: from motivation to action (Willner P, Scheel-Krüger J, eds), pp 199-224. Chichester, UK: Wiley.

Pierce RC, Kalivas PW (1997) A circuitry model of the expression of behavioral sensitization to amphetamine-like psychostimulants. Brain Res Rev 25:192-216.

Pijnenburg AJJ, Honig WMM, Van Rossum JM (1975) Inhibition of $d$-amphetamine-induced locomotor activity by injection of haloperidol into the nucleus accumbens of the rat. Psychopharmacologia 41:87-95.

Plantjé JF, Daus FJ, Hansen HA, Stoof JC (1984) SCH 23390 blocks D-1 and D-2 dopamine receptors in rat neostriatum in vitro. Naunyn Schmiedebergs Arch Pharmacol 327:180-182.

Reith MEA, Li M-Y, Yan Q-S (1997) Extracellular dopamine, norepinephrine, and serotonin in the ventral tegmental area and nucleus accumbens of freely moving rats during intracerebral dialysis following systemic administration of cocaine and other uptake blockers. Psychopharmacology 134:309-317.

Robinson TE, Becker JB (1986) Enduring changes in brain and behavior produced by chronic amphetamine administration: a review and evaluation of animal models of amphetamine psychosis. Brain Res Rev 11:157-198.

Robinson TE, Berridge KC (1993) The neural basis of drug craving: an incentive-sensitization theory of addiction. Brain Res Rev 18:247-291.

Salamone JD (1994) The involvement of nucleus accumbens dopamine in appetitive and aversive motivation. Behav Brain Res 61:117-133.

Schoffelmeer ANM, Hogenboom F, Mulder AH, Ronken E, Stoof JC, Drukarch B (1994) Dopamine displays an identical apparent affinity towards functional dopamine $\mathrm{D}_{1}$ and $\mathrm{D}_{2}$ receptors in rat striatal slices: possible implications for the regulatory role of $\mathrm{D}_{2}$ receptors. Synapse 17:190-195. 
Schoffelmeer ANM, Vanderschuren LJMJ, Van Royen DE, Wardeh G, Hogenboom F, Mulder AH (1998) Lack of $\alpha_{2}$-adrenoceptor autoregulation of noradrenaline release in rat nucleus accumbens slices. Naunyn Schmiedebergs Arch Pharmacol 357:87-90.

Schultz W, Dayan P, Montague PR (1997) A neural substrate of prediction and reward. Science 275:1593-1599.

Seiden LS, Sabol KE, Ricaurte GA (1993) Amphetamine: effects on catecholamine systems and behavior. Annu Rev Pharmacol Toxicol 32:639-677.

Sesack SR, Aoki C, Pickel VM (1994) Ultrastructural localization of $\mathrm{D}_{2}$ receptor-like immunoreactivity in midbrain dopamine neurons and their striatal targets. J Neurosci 14:88-106.
Smiley JF, Levey AI, Ciliax BJ, Goldman-Rakic PS (1994) $\mathrm{D}_{1}$ dopamine receptor immunoreactivity in human and monkey cerebral cortex: predominant and extrasynaptic localization in dendritic spines. Proc Natl Acad Sci USA 91:5720-5724.

Snoddy AM, Tessel RE (1985) Prazosin: effect on psychomotor stimulant cues and locomotor activity in mice. Eur J Pharmacol 116:221-228.

Stoof JC, Kebabian JW (1984) Two dopamine receptors: biochemistry, physiology and pharmacology. Life Sci 35:2281-2296.

Ungerstedt U (1971) Stereotaxic mapping of the monoamine pathways in the rat brain. Acta Physiol Scand Suppl 367:1-48.

Yavich L, Lappalainen R, Sirviö J, Haapalinna A, MacDonald E (1997) $\alpha_{2}$-Adrenergic control of dopamine overflow and metabolism in mouse striatum. Eur J Pharmacol 339:113-119. 